\title{
Rapid Identification of Polyhydroxyalkanoate Accumulating Members of Bacillales Using Internal Primers for phaC Gene of Bacillus megaterium
}

\author{
Pramoda Kumar Nayak, ${ }^{1}$ Ajeet Kumar Mohanty, ${ }^{2}$ Teja Gaonkar,, Ashwani Kumar, \\ Saroj N. Bhosle, ${ }^{1}$ and Sandeep Garg ${ }^{1}$ \\ ${ }^{1}$ Department of Microbiology, Goa University, Taleigao Plateau, Goa 403206, India \\ ${ }^{2}$ National Institute of Malaria Research, Field Station, DHS Building, Campal, Panaji, Goa 403001, India
}

Correspondence should be addressed to Sandeep Garg; sandeep_garg68@yahoo.co.in

Received 16 April 2013; Accepted 5 June 2013

Academic Editors: D. A. Bazylinski, G. Nychas, and A. Poli

Copyright (C) 2013 Pramoda Kumar Nayak et al. This is an open access article distributed under the Creative Commons Attribution License, which permits unrestricted use, distribution, and reproduction in any medium, provided the original work is properly cited.

Bacillus megaterium is gaining recognition as an experimental model and biotechnologically important microorganism. Recently, descriptions of new strains of $B$. megaterium and closely related species isolated from diverse habitats have increased. Therefore, its identification requires several tests in combination which is usually time consuming and difficult to do. We propose using the uniqueness of the polyhydroxyalkanoate synthase $C$ gene of $B$. megaterium in designing primers that amplify the $0.9 \mathrm{~kb}$ region of the phaC for its identification. The PCR method was optimized to amplify $0.9 \mathrm{~kb}$ region of phaC gene. After optimization of the PCR reaction, two methods were investigated in detail. Method I gave an amplification of a single band of $0.9 \mathrm{~kb}$ only in $B$. megaterium and was demonstrated by several strains of $B$. megaterium isolated from different habitats. The use of Method I did not result in the amplification of the phaC gene with other members of Bacillales. The specificity for identification of $B$. megaterium was confirmed using sequencing of amplicon and RT-PCR. Method II showed multiple banding patterns of nonspecific amplicons among polyhydroxyalkanoate accumulating members of Bacillales unique to the respective species. These methods are rapid and specific for the identification of polyhydroxyalkanoate accumulating B. megaterium and members of Bacillales.

\section{Introduction}

Bacillus megaterium is a Gram-positive, aerobic, spore forming bacterium present in diverse habitats from terrestrial to marine sediments. This "big beast" has been identified as an experimental organism for studies on various cell structures and functions $[1,2]$. Its ecological and economical value has been established and reviewed [3-5]. It is only in the past two decades that various new strains of this species with immense potential in industries have been isolated from various ecosystems. The presence of $B$. megaterium in soil has been implicated in the degradation of herbicides and insecticides [6, 7]. Strains of B. megaterium have been recognised for biological control of root infections due to Rhizoctonia solani [8]. Strains producing biomolecules, such as phytohormone, 2-pentylfuran, pyruvate, oxetanocin, vitamin $\mathrm{B} 12$, and polyhydroxyalkanoate (PHA) which are of industrial importance have been investigated [9-12]. This bacterium produces proteins of economical importance, namely, agarase, chitosanase, penicillin G acylase, amylases, glucose dehydrogenase, neutral protease, and the family of P-450 cytochrome monooxygenases [13-15]. Bacillus megaterium is also amenable for recombinant DNA technology for the improvement of specific enzymes and for protein production [5]. Genomes of biotechnologically important strains of B. megaterium have been sequenced in 2011 [16]. Recently, it has been recognised as a promising candidate among Gram-positive organisms for producing polyhydroxyalkanoate on an industrial scale because few strains are capable of accumulating the homopolymer and copolymer in the presence of a single carbon source or inexpensive carbon substrates [17-19]. 
Phenotypic characterization for identification of strains of $B$. megaterium is based on morphology, nutrition, growth, and physiological characteristics including utilisation of various substrates [20-25]. Large variations and inconsistencies in test results make the identification of this species difficult. In the light of this, several methods have been employed for identification of strains of B. megaterium such as DNADNA hybridization [26], analysis of cellular fatty acid content [27], small-subunit-ribosomal RNA sequencing [20, 28], 16S rDNA sequencing [29], randomly amplified polymorphic DNA (RAPD) techniques [30, 31], SDS-PAGE of whole cell protein profiles [32], and PHA inclusion body associated protein profiles [27]. However, these methods are laborious, time consuming and have to be used in combinations.

In the last decade, several new members of Bacillus closely related to Bacillus megaterium have been described. On account of limited differences within closely related species, it is often problematic to differentiate between $B$. megaterium and its closely related Bacillus species using phenotypic characteristics and $16 \mathrm{~S}$ rRNA sequences. This has been further compounded due to the establishment of new genera and groups within Bacillus that has led to the creation of new genera and realignment of several species [33-38]. Lately, many new species in Bacillales have been described. It requires a large number of tests to be performed with caution including RAPD analysis and SDS-PAGE profiling of whole cell proteins or polyhydroxyalkanoate inclusion body associated proteins to identify $B$. megaterium. The present report describes a simple and rapid method for identification of $B$. megaterium using the gene of PHA synthase $\mathrm{C}$ (phaC). Earlier this gene was thought to belong to Class III PHA synthase [39]. Recently, McCool and Cannon [2] reported it as being novel and distinctly different from other known PHA synthases. In the present study amplification of internal portion of $p h a C$ gene was devised as a novel, rapid, and simple technique for identification of Bacillus megaterium. Further, the variant of the method can be used in identifying PHA accumulating members of Bacillales.

\section{Materials and Methods}

2.1. Bacterial Strains and Growth Medium. Bacterial cultures used in the present investigation and their sources are listed in Table 1. All the bacterial isolates were maintained and grown on the respective medium (Table 1). All the bacterial isolates were screened for PHA accumulation on E2-mineral medium containing $2 \% \mathrm{w} / \mathrm{v}$ glucose and visualized with Nile blue A staining method [19]. The bacterial isolates that did not grow on E2-mineral medium were checked for PHA accumulation on nutrient agar plates.

2.2. Quantitative Analysis of PHA. The isolates which showed orange fluorescence on Nile blue A staining method were selected for PHA extraction. These isolates were grown in $250 \mathrm{~mL}$ Erlenmeyer flask containing $100 \mathrm{~mL}$ E2 mineral medium supplemented with glucose $\left(20 \mathrm{~g} \mathrm{~L}^{-1}\right)$ as the sole carbon source. The flask was incubated on an Orbitek environmental shaker $(170 \mathrm{rpm})$ for $48 \mathrm{~h}$ at $30^{\circ} \mathrm{C}$. The bacterial isolates which could not grow in E2 broth were grown in nutrient broth. The bacterial cells were harvested, and PHA was extracted using the sodium-hypochlorite method [19]. Biomass and PHA obtained were quantified gravimetrically afterwards every $24 \mathrm{~h}$ till a constant weight was obtained.

\subsection{Characterization of PHA Using Fourier Transform Infrared Spectroscopy (FTIR). PHA samples were dissolved in chloro- form and made to thin film. The FTIR spectrum of the film of polymer was recorded at $400-4000 \mathrm{~cm}^{-1}$ in FTIR [40].}

2.4. Physiological Characterization. All the strains of Bacillus used in this study were tested for several physiological characteristics using the methods described in Bergey's Manual of Systematic Bacteriology [41, 42]. Tests used in the present study are listed in Table 2.

2.5. Designing Specific Primers. Complete sequences of phaC genes AB525783 (B. megaterium), CP001598 (B. anthracis), HM122246 (B. cereus), GU190695 (B. mycoides), CP001903 (B. thuringiensis), CP000903 (B. weihenstephanensis) and AB077026 (Bacillus sp. INT005) were obtained from the NCBI nucleotide database and used for designing specific primers. The sequences were aligned using Clustal-X in order to search for internal region of phaC gene specific for B. megaterium (Figure 1). A pair of oligonucleotides, forward and reverse, was selected. The primers were BmphaC015F (CGTGCAAGAGTGGGAAAAAT) as forward and BmphaC931R (TCGCAATATGATCACGGCTA) as reverse with $t_{m}$ value $63.9^{\circ} \mathrm{C}$. These were synthesized by Bangalore Genei Pvt. Ltd., Bangalore, India. The sequences and positions of oligonucleotides are presented in Figure 1.

2.6. DNA Extraction. Bacterial isolates were grown in respective media broth at $30^{\circ} \mathrm{C}$. DNA was extracted from $24 \mathrm{~h}$ old culture using the protocol described in Sambrook et al. [43].

2.7. PCR Optimization of phaC. PCR using the internal primers (Figure 1) for phaC was optimized as follows: PCR reactions were performed in a total volume of $50 \mu \mathrm{L}$. The reaction mixture contains $2 \mu \mathrm{L}$ of genomic DNA as a template, 10X PCR buffer [100 mM Tris-HCl (pH 9), $500 \mathrm{mM}$ $\mathrm{KCl}$ and $0.1 \%$ gelatin], $1.5 \mathrm{mM} \mathrm{MgCl}_{2}, 10 \mathrm{mM}$ dNTP Mix, $1 \mu \mathrm{M}-10 \mu \mathrm{M}$ of each primer depending on the requirement, and 5 units/ $\mu \mathrm{L}$ of Taq polymerase (Bangalore Genei, India). Genomic DNA of six bacterial species were used; these were Bacillus megaterium, Bacillus flexus, Bacillus endophyticus, Bacillus sp., Paracoccus yeii, and Pseudomonas aeruginosa. Reactions were carried out in a thermocycler (BIOER XP Cycler, China) consisting of initial denaturation at $94^{\circ} \mathrm{C}$ for 3 minutes, followed by 35 cycles of denaturation at $94^{\circ} \mathrm{C}$ for $1 \mathrm{~min}$, annealing at 51 to $64^{\circ} \mathrm{C}$ (as required) for $1 \mathrm{~min}$, elongation at $72^{\circ} \mathrm{C}$ for $1 \mathrm{~min}$ followed by $72^{\circ} \mathrm{C}$ for $5 \mathrm{~min}$ and final storage at $4^{\circ} \mathrm{C}$. The specificity was optimized by adjusting annealing temperature from 51 to $64^{\circ} \mathrm{C}$ and primer concentration from 1 to $10 \mu \mathrm{M}$. 
TABLE 1: Bacterial cultures: their source and growth medium.

\begin{tabular}{|c|c|c|c|c|c|}
\hline Serial no. & Bacterial species & Medium & Source & $\begin{array}{c}\text { 16S rRNA } \\
\text { sequence } \\
\text { accession no. }\end{array}$ & $\begin{array}{c}\text { PHA } \\
\text { accumulation } \\
(\% \mathrm{w} / \mathrm{w})\end{array}$ \\
\hline 1 & Aneurinibacillus migulanus $81 \mathrm{Al}^{\mathrm{T}}$ & NA & NRS $1137 T^{*}$ & ND & - \\
\hline 2 & B. amyloliquefaciens 10A1 & NA & BGSC $10 \mathrm{Al}^{*}$ & ND & $+(18.246)$ \\
\hline 3 & B. aquimaris & NA & MTCC6722 & AF483625 $\$$ & - \\
\hline 4 & B. coagulans $61 \mathrm{Al}^{\mathrm{T}}$ & NA & ATCC $7050^{*}$ & DQ297928 & $+(15.020)$ \\
\hline 5 & B. cereus $6 \mathrm{~A} 5$ & NA & ATCC $14579^{*}$ & AE016877 $\$$ & - \\
\hline 6 & B. circulans $16 \mathrm{Al}^{\mathrm{T}}$ & NA & ATCC $4513^{*}$ & FJ560956 & $+(18.000)$ \\
\hline 7 & B. endophyticus TMR1.22 & TYGA & $\begin{array}{c}\text { Coastal } \\
\text { sand-dune (R) }\end{array}$ & HQ897169\# & $+(39.409)$ \\
\hline 8 & B. firmus $29 \mathrm{Al}^{\mathrm{T}}$ & NA & NRS $613 \mathrm{~T}^{*}$ & ND & $+(20.078)$ \\
\hline 9 & B. flexus NAMR4.1 & NA & $\begin{array}{c}\text { Coastal } \\
\text { sand-dune (R) }\end{array}$ & HM026605 & $+(47.476)$ \\
\hline 10 & B. licheniformis $5 \mathrm{~A} 1$ & NA & ATCC $8480^{*}$ & ND & - \\
\hline 11 & B. megaterium & NA & MTCC428 & ND & $+(32.630)$ \\
\hline 12 & B. megaterium 7A16 & NA & QM B1551* & СР001983 & $+(32.814)$ \\
\hline 13 & B. megaterium NQ-11/A2 & NA & $\begin{array}{c}\text { Arabian } \\
\text { sea-continental } \\
\text { shelf sediment } \\
\text { sample- } \\
\text { NCIM5334 }\end{array}$ & FJ392860 & $+(61.000)$ \\
\hline 14 & B. megaterium COL1/A6 & NA & Humus sample & EU702754 & $+(65.510)$ \\
\hline 15 & B. megaterium BLQ-2/A7 & NA & $\begin{array}{l}\text { sediment } \\
\text { sample }\end{array}$ & EU924811 ${ }^{\#}$ & $+(59.870)$ \\
\hline 16 & B. megaterium TMR1.3.2 & TYGA & $\begin{array}{c}\text { Coastal } \\
\text { sand-dune (R) }\end{array}$ & GU984576 & $+(39.356)$ \\
\hline 17 & B. megaterium TMR1.4 & TYGA & $\begin{array}{c}\text { Coastal } \\
\text { sand-dune (R) }\end{array}$ & GU951918 & $+(40.801)$ \\
\hline 18 & B. megaterium NAMNR3.7 & NA & $\begin{array}{c}\text { Coastal } \\
\text { sand-dune (NR) }\end{array}$ & GU951917 & $+(41.776)$ \\
\hline 19 & B. mojavensis & NA & MTCC8604 & $\mathrm{AF} 440779^{\$}$ & $+(12.345)$ \\
\hline 20 & B. mycoides $6 \mathrm{~A} 19$ & NA & ATCC $31101^{*}$ & $\mathrm{EF} 210306^{\$}$ & - \\
\hline 21 & B. niacin & NA & MTCC8323 & ND & $+(11.702)$ \\
\hline 22 & B. pumilus $8 \mathrm{~A} 3$ & NA & ATCC $7061^{*}$ & EU138517 $\$$ & $+(23.428)$ \\
\hline 23 & B. simplex & NA & MTCC7284 & ND & $+(26.972)$ \\
\hline 24 & B. spizizenii & NA & ATCC 6633 & $\mathrm{AB} 018486^{\$}$ & - \\
\hline 25 & B. subtilis subsp. subtilis $3 \mathrm{~A} 1$ & NA & NCIB $3610^{*}$ & ND & $+(18.729)$ \\
\hline 26 & Bacillus sp. TMR1.10.1 & TYGA & Sand-dune (R) & HM035484 & $+(51.860)$ \\
\hline 27 & Bacillus sp. NAMNR4.4 & NA & $\begin{array}{c}\text { Coastal } \\
\text { sand-dune (NR) }\end{array}$ & JX194167 & - \\
\hline 28 & Bacillus sp. NAMNR3.5 & NA & $\begin{array}{c}\text { Coastal } \\
\text { sand-dune (NR) }\end{array}$ & JX194166 & $+(23.624)$ \\
\hline 29 & Bacillus sp. TMNR4.1.1 & TYGA & $\begin{array}{c}\text { Coastal } \\
\text { sand-dune (NR) }\end{array}$ & JX194168 & $+(27.369)$ \\
\hline 30 & Bacillus sp. MS4.SE3 & TYGA & $\begin{array}{l}\text { Sediment } \\
\text { sample }\end{array}$ & ND & - \\
\hline 31 & B. thurigiensis $164 \mathrm{H}-14$ & NA & RCPFBS & ND & $+(37.812)$ \\
\hline 32 & B. weihenstephanensis $6 \mathrm{~A} 24$ & NA & BGSC 6A24* & $\mathrm{ND}$ & - \\
\hline 33 & Geobacillus stearothermophilus 9A20 & NA & ATCC $12980^{*}$ & AY $608928^{\$}$ & $+(13.394)$ \\
\hline 34 & Lysinibacillus fusiformis 19A1T & NA & ATCC $7055 T^{*}$ & AF169537 $\$$ & $+(21.794)$ \\
\hline 35 & Lysinibacillus sphaericus $13 \mathrm{~A} 10$ & NA & ATCC $12123^{*}$ & ND & $+(26.785)$ \\
\hline
\end{tabular}


TABLE 1: Continued.

\begin{tabular}{|c|c|c|c|c|c|}
\hline Serial No. & Bacterial species & Medium & Source & $\begin{array}{c}\text { 16S rRNA } \\
\text { sequence } \\
\text { accession no. }\end{array}$ & $\begin{array}{c}\text { PHA } \\
\text { accumulation } \\
(\% \mathrm{w} / \mathrm{w})\end{array}$ \\
\hline 36 & Lysinibacillus sp. KSD-4 & NA & $\begin{array}{l}\text { Stagnant water- } \\
\text { MTCC3672 }\end{array}$ & FJ473365 & $+(25.233)$ \\
\hline 37 & Marinibacillus marinus 21A1T & NA & DSMZ $1297^{*}$ & AJ237708 $\$$ & $+(21.198)$ \\
\hline 38 & Paenibacillus dendritiformis 30A2 & NA & C168* & $\mathrm{AB} 045092^{\$}$ & $+(18.859)$ \\
\hline 39 & Paracoccus yeii TMR3.1 & TYGA & $\begin{array}{c}\text { Coastal } \\
\text { sand-dune (R) }\end{array}$ & GU906275* & $+(28.205)$ \\
\hline 40 & Pseudomonas aeruginosa & NA & ATCC 9027 & ND & - \\
\hline 41 & Pseudomonas aeruginosa TMR2.13 & TYGA & $\begin{array}{c}\text { Coastal } \\
\text { sand-dune (R) }\end{array}$ & HM030825 & - \\
\hline
\end{tabular}

NA: nutrient agar; TYGA: tryptone yeast extract glucose agar; ATCC: American Type Culture Collection, USA; MTCC: Microbial Type Culture Collection, India; NCIM: National Collection of Industrial Micro-organisms, India; RCPFBS: Russian commercial powder formulations Bacticide and Sphericide; BGSC: Bacillus Genetic Stock Center, Columbus; NRRL: Northern Regional Research Laboratory, USA; NCIB: National Collection of Industrial, Marine and Food Bacteria, Scotland; DSMZ: Deutsche Sammlung von Mikroorganismen und Zellkulturen, Germany; NRS: Northern Research Station, USA; ${ }^{*}$ cultures obtained from BGSC; " sequences obtained in current study; ${ }^{\$}$ sequences obtained from NCBI; R: Rhizosphere; NR: nonrhizosphere; PHA: polyhydroxyalkanoate; ND: not done; + and -: Nile Blue A staining method; +: accumulating PHA; -: negative for PHA accumulation; PHA accumulation (\% w/w), gravimetric method.

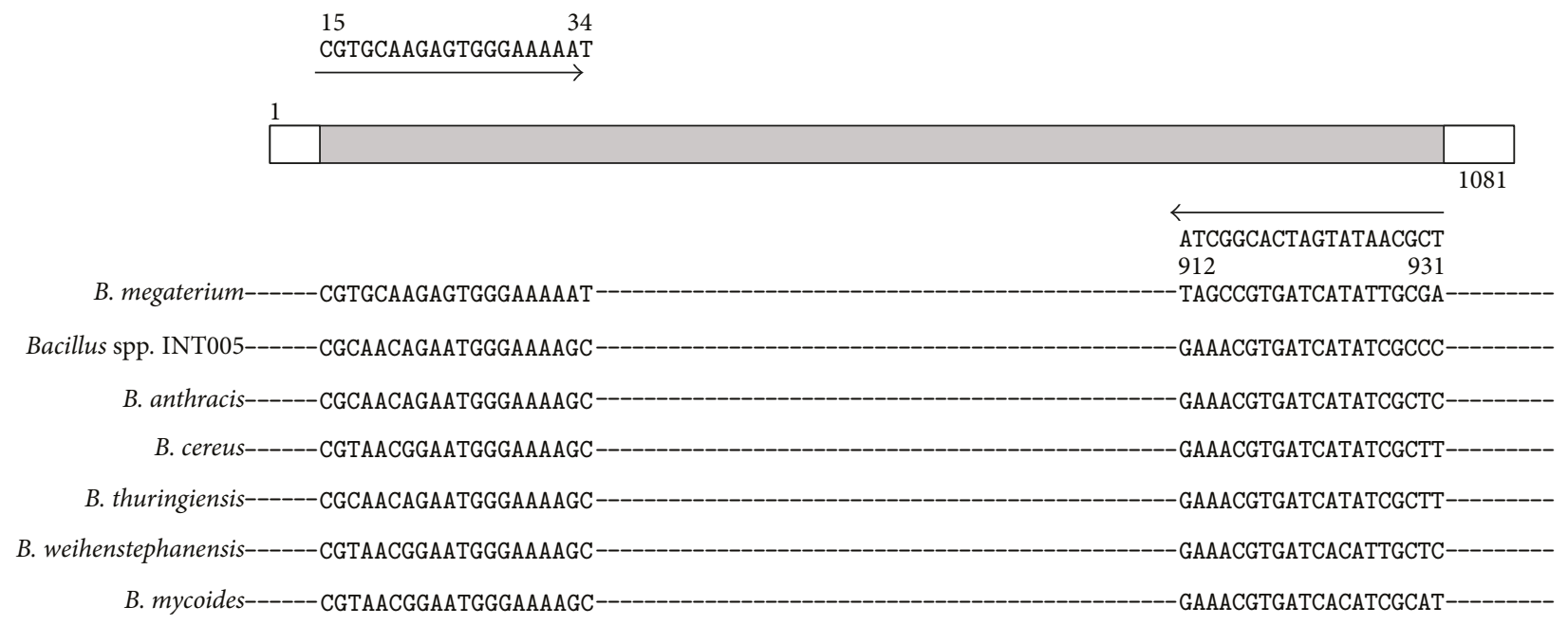

FIGURE 1: Location of forward and reverse primers on phaC gene of B. megaterium. The numbers indicate the positions of the primers on the $p h a C$ gene. The arrow indicates the direction of forward and reverse primers on the gene. Accession numbers of the sequences used to draw the diagram are given in the text.

2.8. Detecting PCR Products. Electrophoresis on $1 \%(\mathrm{w} / \mathrm{v})$ agarose gel was used for detecting PCR amplification products [43]. 100 or $500 \mathrm{bp}$ ladders were used as DNA size marker. Run conditions were 100 volts for 2 hours. The gel was stained with ethidium bromide solution $(0.5 \mu \mathrm{g} / \mathrm{mL})$. Amplified DNA fragments were visualized under UV light and recorded using a Gel-Doc Alpha Imager (Alpha Innotech, USA).

2.9. Validating PCR. Amplified products from strains $B$. megaterium TMR1.3.2 and B. megaterium TMR1.4 under optimum conditions having expected size were purified using purification kit (Quaigen, India) and were sequenced using forward primer (BmphaC015F) at Bangalore Genei, India. Sequences obtained were compared with sequences in the NCBI nucleotide database using Blastn. Sequences were deposited in GenBank. Amplified nucleotide sequences were analyzed and aligned with the reference sequences of phaC of various bacterial species using ClustalX [44], and neighborjoining (NJ) tree was obtained with 1000 seeds and 10000 bootstraps. The final tree obtained was rooted and drawn using MEGA 4.0 [45].

Optimized PCR conditions with $1 \mu \mathrm{M}$ primer concentration and $64^{\circ} \mathrm{C}$ annealing temperature were used for the amplification of $0.9 \mathrm{~kb}$ from phaC of B. megaterium by SYBR green based real-time PCR [46]. The melting curve of the amplicon was performed from 55 to $94^{\circ} \mathrm{C}$ for detecting $t_{m}$ of amplicon.

All the bacterial isolates mentioned in Table 1 were used for PCR amplification of phaC at optimum conditions (Method I) of $1 \mu \mathrm{M}$ primer concentration and $64^{\circ} \mathrm{C}$ annealing temperature and suboptimal conditions (Method II) of $10 \mu \mathrm{M}$ 


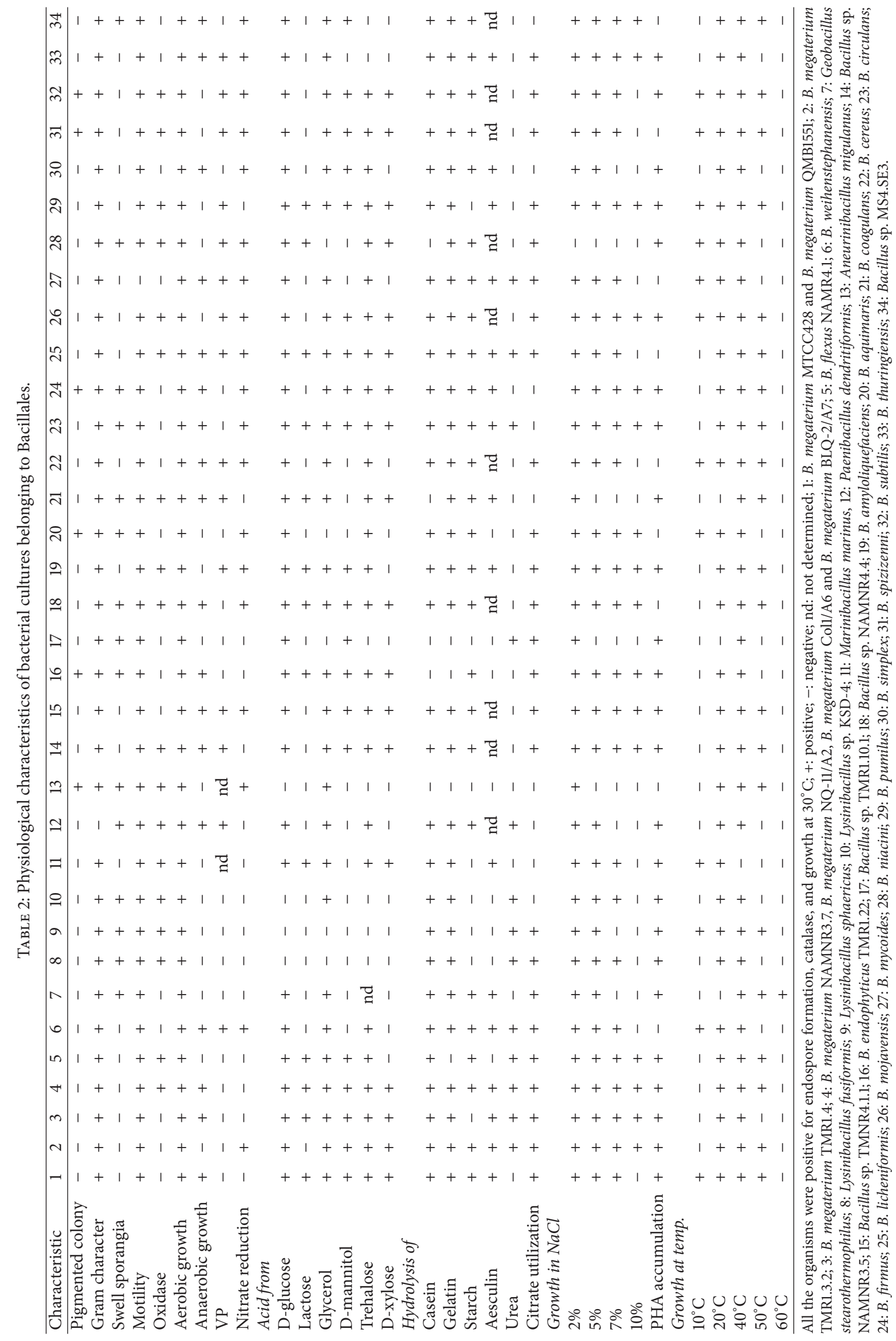


TABLE 3: Optimization of PCR condition for amplification of internal region of phaC gene using primer set described in Figure 1.

\begin{tabular}{|c|c|c|c|c|c|c|c|c|c|c|c|c|c|}
\hline \multirow{4}{*}{ Primer $(\mu \mathrm{M})$} & \multirow{4}{*}{$\begin{array}{c}\text { Annealing } \\
\text { temperature }\left({ }^{\circ} \mathrm{C}\right)\end{array}$} & \multicolumn{12}{|c|}{ Bacterial species } \\
\hline & & \multirow{2}{*}{\multicolumn{2}{|c|}{$\begin{array}{c}\text { B. megaterium } \\
\text { (MTCC428) } \\
\text { PHA + }\end{array}$}} & \multirow{2}{*}{\multicolumn{2}{|c|}{$\begin{array}{c}\text { B. flexus } \\
\text { (NAMR4.1) } \\
\text { PHA + }\end{array}$}} & \multirow{2}{*}{\multicolumn{2}{|c|}{$\begin{array}{c}\text { B. endophyticus } \\
\text { (TMR1.22) } \\
\text { PHA + }\end{array}$}} & \multirow{2}{*}{\multicolumn{2}{|c|}{$\begin{array}{c}\text { Bacillus sp. } \\
\text { (NAMNR4.4) } \\
\text { PHA - }\end{array}$}} & \multirow{2}{*}{\multicolumn{2}{|c|}{$\begin{array}{c}\text { P. yeii } \\
\text { (TMR3.1) } \\
\text { PHA + }\end{array}$}} & \multirow{2}{*}{\multicolumn{2}{|c|}{$\begin{array}{c}\text { P. aeruginosa } \\
\text { (TMR2.13) } \\
\text { PHA - }\end{array}$}} \\
\hline & & & & & & & & & & & & & \\
\hline & & $0.9 \mathrm{~Kb}$ & $\mathrm{MB}$ & $0.9 \mathrm{~Kb}$ & $\mathrm{MB}$ & $0.9 \mathrm{~Kb}$ & MB & $0.9 \mathrm{~Kb}$ & $\mathrm{MB}$ & $0.9 \mathrm{~Kb}$ & $\mathrm{MB}$ & $0.9 \mathrm{~Kb}$ & $\mathrm{MB}$ \\
\hline \multirow{4}{*}{1} & 51 & + & - & - & - & - & - & - & - & - & - & - & - \\
\hline & 55 & + & - & - & - & - & - & - & - & - & - & - & - \\
\hline & 60 & + & - & - & - & - & - & - & - & - & - & - & - \\
\hline & 64 & + & - & - & - & - & - & - & - & - & - & - & - \\
\hline \multirow{4}{*}{2.5} & 51 & + & - & - & - & - & - & - & - & - & - & - & - \\
\hline & 55 & + & - & - & - & - & - & - & - & - & - & - & - \\
\hline & 60 & + & - & - & - & - & - & - & - & - & - & - & - \\
\hline & 64 & + & - & - & - & - & - & - & - & - & - & - & - \\
\hline \multirow{4}{*}{5} & 51 & + & * & - & + & - & + & - & - & - & - & - & - \\
\hline & 55 & + & $*$ & - & + & - & + & - & - & - & - & - & - \\
\hline & 60 & + & * & - & + & - & + & - & - & - & - & - & - \\
\hline & 64 & + & $*$ & - & - & - & - & - & - & - & - & - & - \\
\hline \multirow{4}{*}{10} & 51 & + & $*$ & - & + & - & + & - & - & - & - & - & - \\
\hline & 55 & + & $*$ & - & + & - & + & - & - & - & - & - & - \\
\hline & 60 & + & * & - & + & - & + & - & - & - & - & - & - \\
\hline & 64 & + & $*$ & - & - & - & - & - & - & - & - & - & - \\
\hline
\end{tabular}

PHA +: polyhydroxyalkanoate accumulating bacteria; PHA -: bacteria not accumulating polyhydroxyalkanoate; $*$ : double band; MB: multiple band; +: positive; $-:$ absent.

and $51^{\circ} \mathrm{C}$. Presence of genomic DNA was confirmed using amplification of 16S rRNA gene using universal primers as a positive control [12]. Entire experimental sets were repeated thrice to determine the reproducibility of Method I and Method II.

A blind folded test was carried out using a few bacterial isolates. B. megaterium BLQ-2/A7 and B. simplex MTCC7284, known for PHA accumulation, were taken as positive controls. Other six bacteria were randomly selected from genus Bacillus. These were not reported for PHA accumulation earlier. Three of these strains were $B$. aquimaris MTCC6722, B. mojavensis MTCC8604, and B. niacin MTCC8323 and three were unidentified Bacillus sp. NAMNR3.5, Bacillus sp. TMNR4.1.1, and Bacillus sp. MS4.SE3 (Table 1). These bacterial isolates were tested for biochemical characteristics, PHA accumulation, and PCR amplification using Method I and Method II. All the experiments were repeated three times.

\section{Results}

3.1. PHA Accumulation. All the bacterial cultures used in the present investigation were tested for their ability to accumulate PHA on solidified E2-mineral medium with $2 \%$ $\mathrm{w} / \mathrm{v}$ glucose (Table 1 ). B. aquimaris and B. niacin did not show any growth on E2-mineral medium. These strains were grown on nutrient agar and screened for PHA accumulation. All the strains of B. megaterium showed PHA accumulation. Aneurinibacillus migulanus, B. aquimaris, $B$. cereus, B. licheniformis, B. mycoides, B. spizizenii, Bacillus sp. NAMNR4.4, Bacillus sp. MS4.SE3, B. weihenstephanensis, and Pseudomonas aeruginosa did not show PHA accumulation. The remaining strains showed PHA accumulation.

3.2. Quantitative Analysis and Characterization of PHA. The PHA content of all the bacterial isolates was found between 10 to $66 \% \mathrm{w} / \mathrm{w}$ (Table 1). PHA content varied among the isolates of $B$. megaterium. FTIR spectroscopy of PHA extracted from all the bacterial isolates showed intense absorptions typical to PHA at $1724-1740 \mathrm{~cm}^{-1}$ and at $1280 \mathrm{~cm}^{-1}$ corresponding to $\mathrm{C}=\mathrm{O}$ and $\mathrm{C}-\mathrm{O}$ stretching groups in ester, respectively.

3.3. Physiological Characteristics. The physiological characteristics of the Bacillus strains are listed in Table 2. All the Bacillus strains are endospore producers, catalase positive and showed growth at $30^{\circ} \mathrm{C}$. Different strains of $\mathrm{B}$. megaterium including the type strain QM B1551 showed variations in the physiological tests and accordingly are separated in Sections 1 to 4 in Table 2 .

3.4. PCR Optimization. PCR optimization of internal region of phaC BmphaC015F and BmphaC931R primers were used for amplifying phaC gene. Different annealing temperatures such as $51,55,60$, and $64^{\circ} \mathrm{C}$ and different primer concentrations such as $1,2.5,5$, and $10 \mu \mathrm{M}$ were used for optimization (Table 3). It was seen that, in B. megaterium at different annealing temperatures with primer concentrations of 1 and 
$2.5 \mu \mathrm{M}$, there was amplification of a single band of $0.9 \mathrm{~kb}$. With primer concentrations of 5 and $10 \mu \mathrm{M}$ along with $0.9 \mathrm{~kb}$ an additional faint band of $1.9 \mathrm{~kb}$ was present. In $B$. flexus and $B$. endophyticus at annealing temperatures 51, 55, 60, and $64^{\circ} \mathrm{C}$ with primer concentrations 1 and $2.5 \mu \mathrm{M}$ there was no amplification, and, with primer concentrations of 5 and $10 \mu \mathrm{M}$, multiple bands were seen in all the temperatures except at $64^{\circ} \mathrm{C}$. PHA accumulating $P$. yeii and PHA negative $P$. aeruginosa and Bacillus species gave no amplification with any combination tested. It was observed that the $0.9 \mathrm{~kb}$ fragment was amplified only in B. megaterium and not amplified in any other bacterial isolate used in this study. When the primer concentration was increased above $5 \mu \mathrm{M}$ with annealing temperature $\leq 60^{\circ} \mathrm{C}$, multiple bands were detected in PHA accumulating Bacillus species, but no amplification was detected in Gram-negative PHA accumulating $P$. yeii, PHA negative Bacillus species, and $P$ aeruginosa. The optimum conditions chosen for PCR amplification of phaC of $B$. megaterium were annealing temperature $=64^{\circ} \mathrm{C}$ and primer concentration $=1 \mu \mathrm{M}$.

3.5. Validation of Method. Observations of PCR amplifications using primer set performed with all the bacterial cultures at optimal conditions (Method I) are seen in Figures 2 and 4(a) and under suboptimal conditions (Method II) in Figures 3 and 4(b). PCR amplification of phaC in all the strains of $B$. megaterium was of a single band of $0.9 \mathrm{~kb}$ fragment in Method I $\left(1 \mu \mathrm{M}\right.$ primer concentration and $64^{\circ} \mathrm{C}$ annealing temperature). No amplification was detected in bacterial species other than $B$. megaterium. 16S rRNA gene was amplified in all the bacterial isolates.

PCR amplification in Method II $(10 \mu \mathrm{M}$ primer concentration and $51^{\circ} \mathrm{C}$ annealing temperature) showed presence of two bands in all the strains of B. megaterium with sizes $0.9 \mathrm{~kb}$ and $1.9 \mathrm{~kb}$. Interestingly, members of Bacillales accumulating PHA showed multiple bands of nonspecific amplicons unique to their respective species. Strains of $B$. licheniformis, $B$. cereus, $B$. mycoides, and $B$. weihenstephanensis did not show any amplification in Method II. Other than B. megaterium, none of the isolates showed presence of the $0.9 \mathrm{~kb}$ band of amplification. All other bacterial species tested in present study did not show any band in PCR amplification. The banding pattern showed complete reproducibility during repeated extractions and amplifications using Method I and Method II. A two-percent deviation was noted in molecular weights of bands.

Results of PCR amplification of Method I and Method II using eight additional bacterial isolates as a part of the blind folded experiment are seen in Figure 5. In Method I only the strain of B. megaterium BLQ-2/A7 showed amplification of $0.9 \mathrm{~kb}$ fragment, whereas no amplification was observed with other bacterial strains. Method II showed amplification of two bands $(0.9 \mathrm{~kb}$ and $1.9 \mathrm{~kb})$ in $B$. megaterium, and nonspecific bands were observed in PHA accumulating $B$. mojavensis MTCC8604, B. niacin MTCC8323, B. simplex MTCC7284, Bacillus sp. NAMNR3.5, and Bacillus sp. TMNR4.1.1. The strains B. aquimaris MTCC6722 and Bacillus sp. MS4.SE3 showed no PHA accumulation and did not give amplification with Method II.

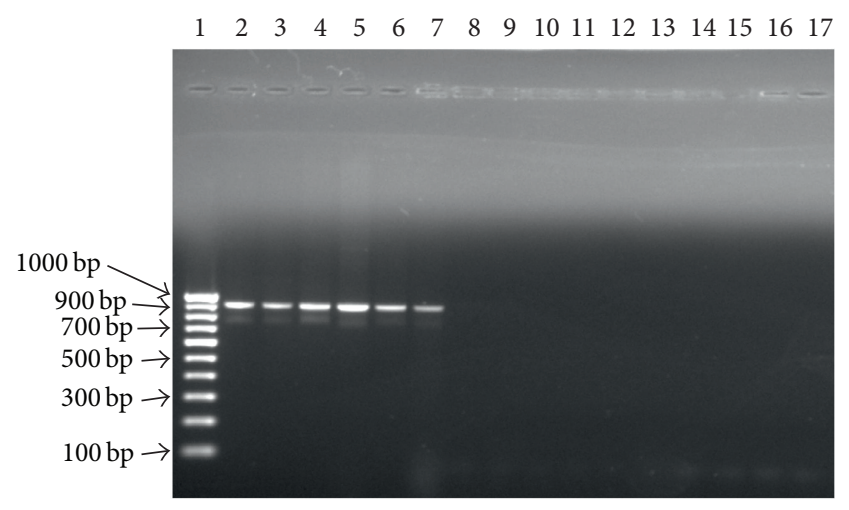

FIgURE 2: PCR amplification of $0.9 \mathrm{~kb}$ internal region of phaC gene under optimum condition (Method I), that is, $1 \mu \mathrm{M}$ of each primer concentration and $64^{\circ} \mathrm{C}$ annealing temperature, where Lane 1-molecular weight marker; 2-Bacillus megaterium MTCC428; 3-Bacillus megaterium TMR1.3.2; 4-Bacillus megaterium TMR1.4; 5-Bacillus megaterium NAMNR3.7; 6-Bacillus megaterium NQ-11/A2; 7-Bacillus megaterium COL1/A6; 8Bacillus flexus NAMR4.1; 9-Bacillus endophyticus TMR1.22; 10Bacillus thuringiensis 164(H-14); 11-Bacillus sphaericus KSD-4; 12-Bacillus sp. TMR1.10.1; 13-Paracoccus yeii TMR3.1; 14Bacillus spizizenii ATCC 6633; 15-Pseudomonas aeruginosa ATCC 9027; 16-Bacillus sp. NAMNR4.4; 17-Pseudomonas aeruginosa TMR2.13.

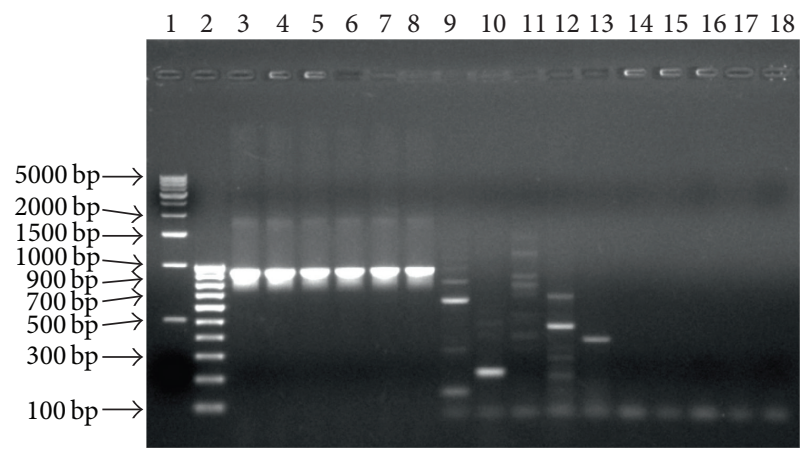

FIGURE 3: PCR amplification of $0.9 \mathrm{~kb}$ internal region of phaC gene in Method II, that is, $10 \mu \mathrm{M}$ of each primer concentration and $51^{\circ} \mathrm{C}$ annealing temperature, where Lane $1-$ molecular weight marker (500 bp); 2-molecular weight marker (100 bp); 3-Bacillus megaterium MTCC 428; 4-Bacillus megaterium TMR1.3.2; 5-Bacillus megaterium TMR1.4; 6-Bacillus megaterium NAMNR3.7; 7Bacillus megaterium NQ-11/A2; 8-Bacillus megaterium COL1/A6; 9-Bacillus flexus NAMR4.1; 10-Bacillus endophyticus TMR1.22; 11-Bacillus thuringiensis 164(H-14); 12-Bacillus sphaericus KSD-4; 13-Bacillus sp. TMR1.10.1;14-Paracoccus yeii TMR3.1; 15-Bacillus spizizenii ATCC 6633; 16-Pseudomonas aeruginosa ATCC 9027; 17-Bacillus sp. NAMNR4.4; 18-Pseudomonas aeruginosa TMR2.13.

The dendogram constructed using multiple banding patterns of amplicon showed all the strains of Bacillales clustered differently (Figure 6). Each pattern of band showed a very little similarity to each other. Further, Method II gave multiple banding patterns for PHA accumulating Bacillus subtilis subsp. subtilis but did not give any amplification for non-PHA accumulator Bacillus subtilis subsp. spizizenii. 


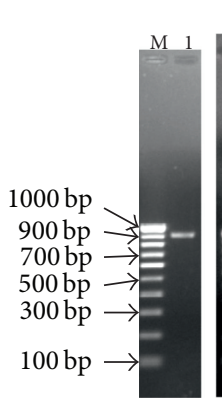

(a)

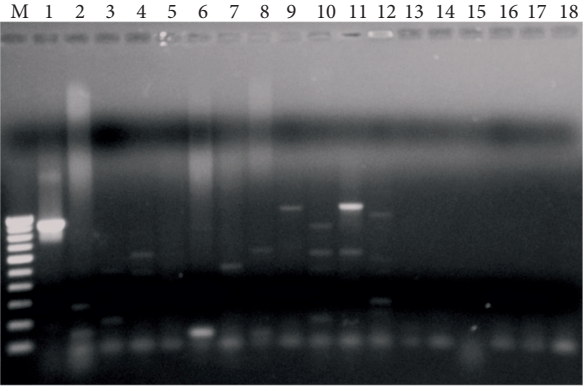

(b)
Figure 4: (a) PCR amplification of $0.9 \mathrm{~kb}$ internal region of phaC gene under optimum condition (Method I), where Lane Mmolecular weight marker (100 bp); 1-Bacillus megaterium QM B1551. (b) PCR amplification of $0.9 \mathrm{~kb}$ internal region of phaC gene in Method II. Where Lane $\mathrm{M}-$ molecular weight marker (100 bp); 1-Bacillus megaterium QM B1551; 2-Bacillus pumilus ATCC 7061; 3-Bacillus amyloliquefaciens BGSC 10A1; 4-Bacillus Coagulans ATCC 7050; 5-Bacillus firmus NRS 613T; 6-Geobacillus stearothermophilus ATCC 12980; 7-Bacillus subtilis subsp. subtilis NCIB 3610; 8-Paenibacillus dendritiformis C168; 9-Marinibacillus marinus DSMZ 1297; 10 - Lysinibacillus sphaericus ATCC 12123; 11Lysinibacillus fusiformis ATCC 7055T; 12-Bacillus circulans ATCC 4513; 13-Bacillus mycoides ATCC 31101; 14-Bacillus weihenstephanensis BGSC 6A24; 15-Bacillus licheniformis ATCC 8480; 16Aneurinibacillus migulanus NRS 1137T; 17-Bacillus cereus ATCC 14579; 18-negative control.

$\begin{array}{llllllllllllllllll}M & 1 & 2 & 3 & 4 & 5 & 6 & 7 & 8 & M & 9 & 10 & 11 & 12 & 13 & 14 & 15 & 16\end{array}$

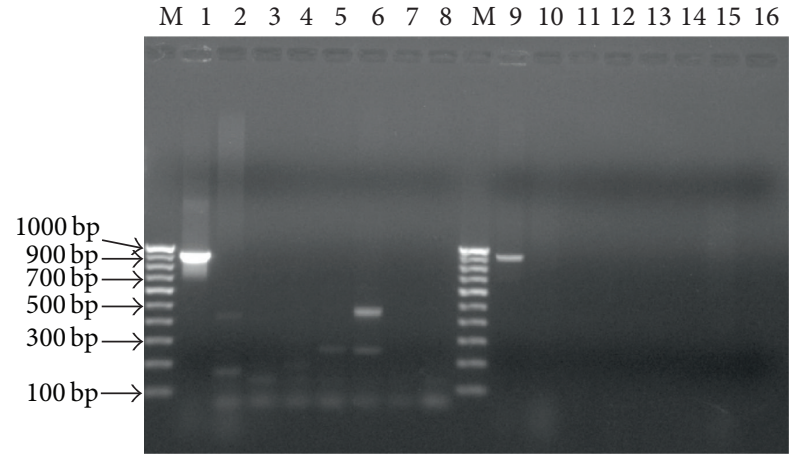

FIGURE 5: PCR amplification of $0.9 \mathrm{~kb}$ internal region of phaC in Method II (Lane 1-8) and Method I (Lane 9-16), where Lane $\mathrm{M}$-molecular weight marker (100 bp); 1-Bacillus megaterium BLQ-2/A7; 2-Bacillus niacini MTCC 8323; 3-Bacillus simplex MTCC 7284; 4-Bacillus mojavensis MTCC 8604; 5Bacillus sp. NAMNR3.5; 6-Bacillus sp. TMNR4.1.1; 7-Bacillus aquimaris MTCC 6722; 8-Bacillus sp. MS4.SE3; M-molecular weight marker (100 bp); 9-Bacillus megaterium BLQ-2/A7; 10Bacillus niacini MTCC 8323; 11-Bacillus simplex MTCC 7284; $12-$ Bacillus mojavensis MTCC 8604; 13-Bacillus sp. NAMNR3.5; 14Bacillus sp. TMNR4.1.1; 15-Bacillus aquimaris MTCC 6722; 16Bacillus sp. MS4.SE3.

The clusters formed due to multiple bands among members of Bacillales were different from the clustering obtained with $16 \mathrm{~S}$ rRNA gene of these species. Method II therefore was able to discriminate PHA accumulating Bacillales up to species level. Although the results were reproducible, it is recommended that it should be used cautiously in combination with other methods.

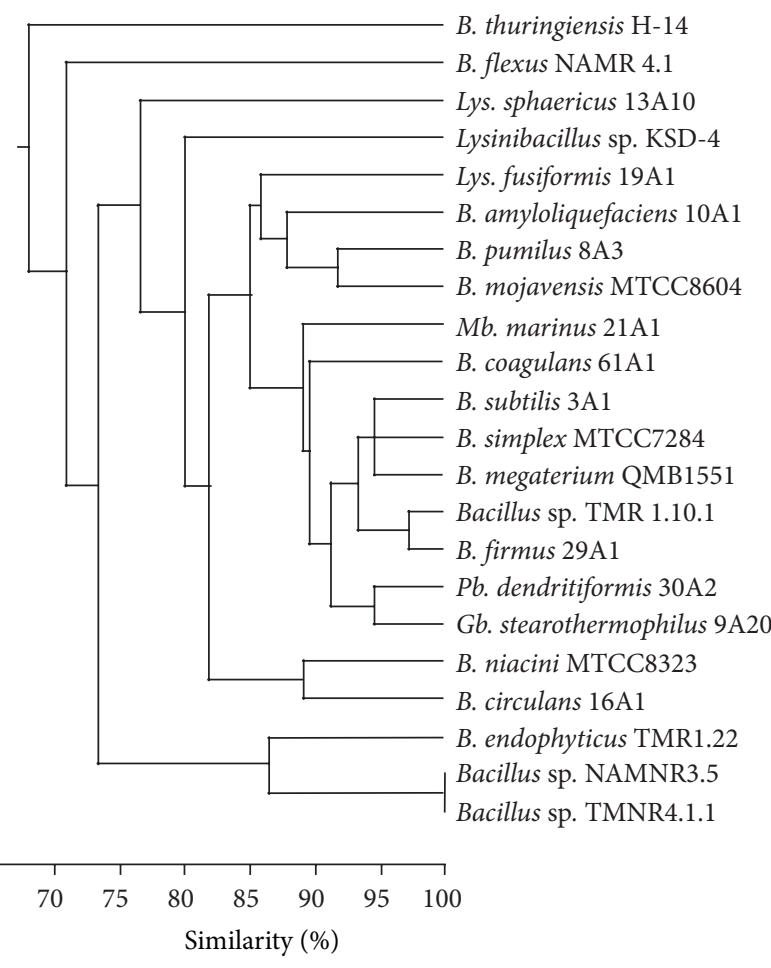

Figure 6: Dendogram of multiple banding patterns obtained in different PHA accumulating Bacillus species. Clustering was achieved by unweighted pair group average linkage (UPGMA). The computations were performed using the Probiosys Software.

The melting curve of amplicon from B. megaterium TMR1.4 showed the presence of a single peak at $85^{\circ} \mathrm{C}$. This confirms the specificity of the primers for the amplification of $0.9 \mathrm{~kb}$ of phaC in B. megaterium.

PCR products of $0.9 \mathrm{~kb}$ obtained with Bacillus megaterium TMR1.3.2 and Bacillus megaterium TMR1.4 were sequenced and deposited in GenBank with accession numbers JF423932 and JF423933, respectively. Nucleotide blast of these sequences showed $100 \%$ similarity with phaC gene of $B$. megaterium. Pairwise alignment of sequences obtained from B. megaterium TMR1.4 with phaC of other Bacillus sp. showed 73-75\% similarity with B. anthracis, B. cereus, B. mycoides, $B$. thuringiensis, and B. weihenstephanensis. Phylogenetic tree constructed using these sequences with sequences of $p h a C$ of various species showed alignment of the sequences with $p h a C$ of B. megaterium (Figure 7).

\section{Discussion}

Polyhydroxyalkanoate production in bacteria is mediated by polyhydroxyalkanoate synthase. This enzyme has been classified into four classes, that is, Class I to Class IV. In B. megaterium, rapid PHA production occurs after a long lag phase. A $4,104 \mathrm{bp}$ cluster consists of five pha genes responsible for PHA synthesis in this bacterium. It consists of phaP, phaQ, phaR, phaB, and phaC. PHA synthase of $B$. megaterium is a heterodimer and belongs to Class IV. This PHA synthase consists of $40 \mathrm{kDa} \mathrm{PhaC}$ and $20 \mathrm{kDa}$ PhaR. Genes of both these proteins are parts of an operon consisting 


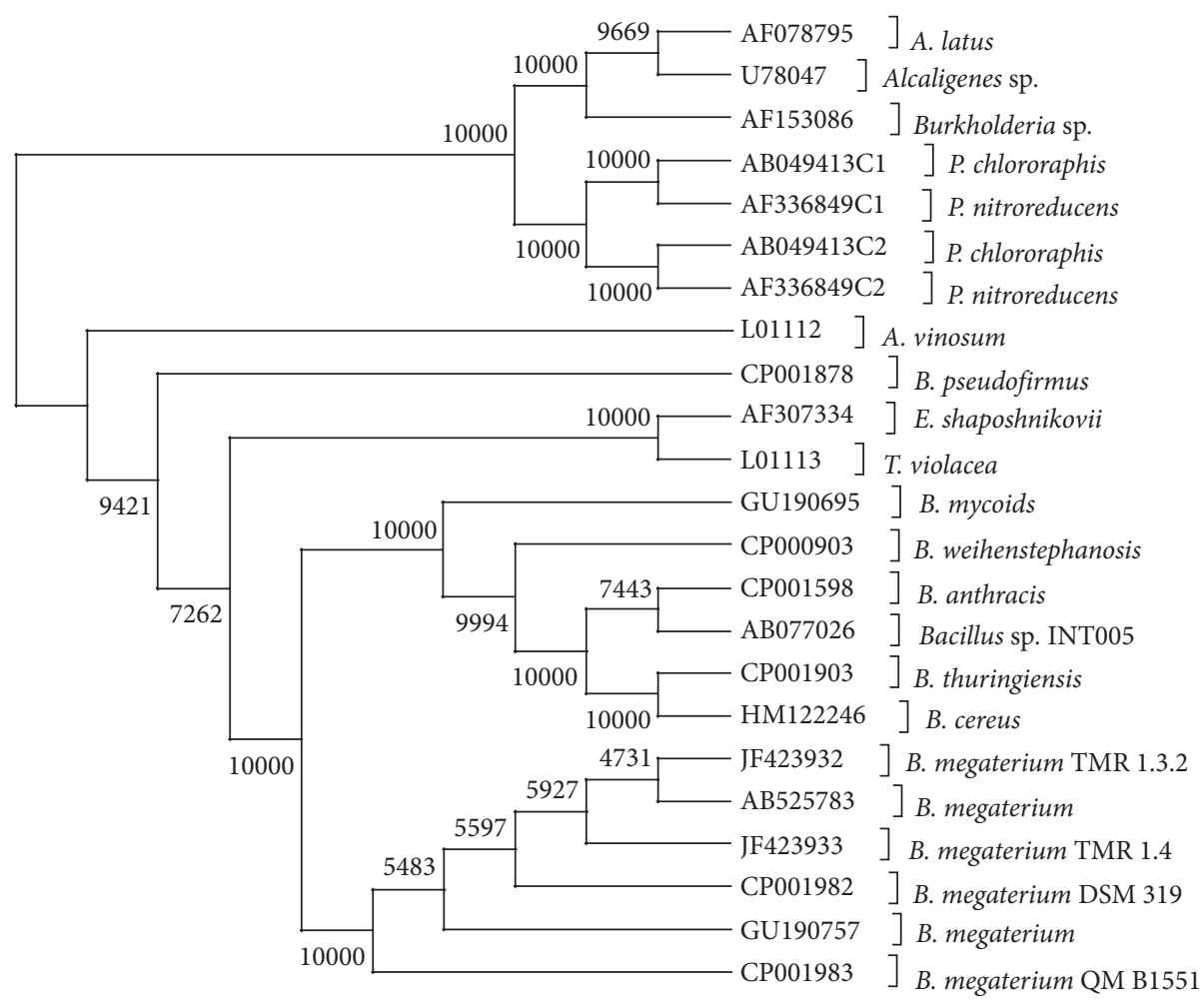

Figure 7: Phylogenetic tree of phaC genes of various bacterial species. The tree was constructed using 1000 seeds and 10000 bootstraps. Except for the strains B. megaterium TMR1.3.2 and B. megaterium TMR1.4 all the sequences used were complete. The node presents the value of bootstrap obtained out of 10000 .

of phaR, phaB, and phaC. These three genes are transcribed as tricistronic mRNA. The phaB encodes for acetoacetyl CoA reductase, which provides hydroxybutyryl CoA for PHA synthase $[2,47,48]$. PhaQ is a DNA binding protein, which represses its own synthesis. Once $\mathrm{PHB}$ is produced, it binds to PhaQ resulting in the removal of repression on transcription of $p h a Q$ and phaP [49]. The phaQ and phaP are transcribed independently as a single mRNA $1.2 \mathrm{~kb}$ that is presumably processed to give $0.7 \mathrm{~kb}$ transcript responsible synthesis of phasins protein-PhaP. Once the phasins are produced, the granule formation of PHA in $B$. megaterium gets stabilized [47]. Bacillus megaterium contains budding granules of $\mathrm{PHB}$ in which PHA synthase is covalently bound [12].

Nucleotide sequences of phaC gene from B. megaterium showed $73-75 \%$ homology with phaC gene of other polyhydroxyalkanoate accumulating Bacillus sp. This indicates the uniqueness of the sequences of phaC of $B$. megaterium. The differences in the gene sequences serving as recognition of unique regions present at 15-34 and 912-931 on phaC were utilised to design the primers for identification of $B$. megaterium. Earlier Shamala et al. [50] designed a set of primer using phaC gene sequences of $B$. megaterium for the detection of PHA producing Bacillus sp., where the amplification product was $590 \mathrm{bp}$ in different PHA accumulating Bacillus sp. including B. megaterium. In the present study the internal primers designed are unique and bind in the phaC gene at 15-34 (forward primer) and 912-931 (reverse primer). PCR amplification using this primer set results in single amplicon of $0.9 \mathrm{~kb}$ seen only in $B$. megaterium at specified optimum conditions. Specificity of the primers was validated by sequencing of $0.9 \mathrm{~kb}$ PCR amplification product from $B$. megaterium, that gave $100 \%$ similarity with phaC of B. megaterium, and real-time PCR that gave $T_{m}$ of the amplicon as $85^{\circ} \mathrm{C}$. Recently genomes of two strains of Bacillus megaterium namely QM B1551 and DSM 319 were sequenced completely [16]. One strain, namely, QM B1551 was incorporated for cross verification of specificity of the primers and method thereof. The method showed amplification of $0.9 \mathrm{~kb}$ fragment with this strain. This confirms the specificity of the primers. The ubiquity of $B$. megaterium in the natural environment and its emerging industrial importance could help if the identification of new potential strains of this bacterium becomes rapid and easier. In comparison to routinely used molecular methods for identification of B. megaterium, the present method is rapid and specific. Further, this method does not require sequencing of amplicon or any additional test to confirm its identification.

PCR based randomly amplified polymorphic DNA (RAPD) technique has been used for molecular typing and identification among closely related species of the genus Bacillus [30, 31]. The pattern of amplified DNA fragments produce during RAPD-PCR provides information on genetic variability between organisms of different species. Interestingly, in Method II B. megaterium and other PHA producing Bacillales gave multiple banding patterns of nonspecific amplicon unique to respective species. Members of Bacillales such as Lysinibacillus, Marinibacillus, Geobacillus, Aneurinibacillus, Paenibacillus, and all the species of Bacillus reported 
for accumulation of PHA were included. Although, B. licheniformis, B. cereus, B. mycoides, and B. weihenstephanensis were reported as PHA accumulators, the isolates of these species used in this study neither showed PHA accumulation nor any amplification in Method II.

Different methods have been used for the identification of B. megaterium which are both laborious and time consuming. During the last decade a number of new species of the genus Bacillus have been described showing a very close similarity to $B$. megaterium. This has resulted in a difficulty in accurate nomenclature of the isolates. Even though several methods are used, the identification is limited to genus level only $[19,27]$. It is known that, among the members of Bacillales, $B$. flexus and $B$. simplex show very close similarity with $B$. megaterium in physiological characteristics and 16S rRNA sequencing, but in this study PCR amplification of the $0.9 \mathrm{~kb}$ region of phaC gene under optimum condition resulted in no amplification in $B$. flexus and $B$. simplex. Pairwise alignment of $16 \mathrm{~S}$ rRNA sequences of $B$. megaterium and $B$. flexus showed 11 nucleotide differences in the hypervariable region in between 150 and 200 bp region of their $16 S$ rRNA gene. Inconsistency in biochemical test results and errors in sequencing of $16 \mathrm{~S}$ rRNA gene may lead to wrong identification. Hence, this method can be ideally used to differentiate B. megaterium from $B$. flexus and $B$. simplex. With the increasing importance of $B$. megaterium in the field of biotechnology, the ambiguity observed with its identification by conventional biochemical and molecular methods would limit its application. The present simple yet rapid method counteracts these problems and is thus a suitable alternative for the accurate identification of the organism.

Like B. megaterium other members of Bacillales are attractive industrial organisms with known capabilities to produce enzymes, recombinant proteins, antibiotics, purine nucleotides, insecticidal proteins, vitamins, sugars biopolymer, and biofertilizers [51-57]. These strains are gaining interest for economic production of these compounds for a variety of reasons including high growth rates, short fermentation cycle times, ability to tolerate wide $\mathrm{pH}$ and temperature ranges, easy to maintain in spore forms, capacity to secrete proteins into the extracellular medium, amenable to genetic engineering, and the GRAS (generally regarded as safe) status [55]. Further, the suboptimal conditions described as Method II were suitable for rapid differentiation for identification of polyhydroxyalkanoate accumulating members of Bacillales.

\section{Abbreviations}

PHA: Polyhydroxyalkanoate

PHB: Polyhydroxybutyrate

phaC: Polyhydroxyalkanoate synthase

PCR: $\quad$ Polymerase chain reaction

RT-PCR: Real-time PCR

RAPD: Randomly amplified polymorphic DNA.

\section{Acknowledgments}

The support from MOES, Government of India, for the Junior Research Fellowship to Pramoda Kumar Nayak under the Center of Excellence in Marine Microbiology, Goa Unversity is gratefully acknowledged. The authors like to thank the Bacillus Genetic Stock Center (BGSC), Columbus, for providing bacterial culture and Mr. Swapnil Doijad and Dr. S. B. Barbuddhe ICAR, ELA-Old Goa, India, for the RT-PCR.

\section{References}

[1] S. Hrafnsdóttir, J. W. Nichols, and A. K. Menon, "Transbilayer movement of fluorescent phospholipids in Bacillus megaterium membrane vesicles," Biochemistry, vol. 36, no. 16, pp. 49694978, 1997.

[2] G. J. McCool and M. C. Cannon, "PhaC and $P h a R$ are required for polyhydroxyalkanoic acid synthase activity in Bacillus megaterium," Journal of Bacteriology, vol. 183, no. 14, pp. 4235-4243, 2001.

[3] Z. L. Liu and B. J. Sinclair, "Population dynamics of Bacillus megaterium strain B153-2-2 in the rhizosphere of soybean," Phytopathology, vol. 82, pp. 1297-1301, 1992.

[4] N. I. López, J. A. Ruiz, and B. S. Méndez, "Survival of poly3-hydroxybutyrate-producing bacteria in soil microcosms," World Journal of Microbiology and Biotechnology, vol. 14, no. 5, pp. 681-684, 1998.

[5] P. S. Vary, R. Biedendieck, T. Fuerch et al., "Bacillus megateriumfrom simple soil bacterium to industrial protein production host," Applied Microbiology and Biotechnology, vol. 76, no. 5, pp. 957-967, 2007.

[6] A. Saxena, R. Zhang, and J.-M. Bollag, "Microorganisms capable of metabolizing the herbicide metolachlor," Applied and Environmental Microbiology, vol. 53, no. 2, pp. 390-396, 1987.

[7] J. P. Quinn, J. M. M. Peden, and R. E. Dick, "Carbon-phosphorus bond cleavage by Gram-positive and Gram-negative soil bacteria," Applied Microbiology and Biotechnology, vol. 31, no. 3, pp. 283-287, 1989.

[8] B. L. Bertagnolli, F. K. Dal Soglio, and J. B. Sinclair, "Extracellular enzyme profiles of the fungal pathogen Rhizoctonia solani isolate $2 \mathrm{~B}-12$ and of two antagonists, Bacillus megaterium strain B153-2-2 and Trichoderma harzianum isolate Th008. I. Possible correlations with inhibition of growth and biocontrol," Physiological and Molecular Plant Pathology, vol. 48, no. 3, pp. 145-160, 1996.

[9] M. G. Sokolova, G. P. Akimova, and O. B. Vaishlya, "Effect of phytohormones synthesized by rhizosphere bacteria on plants," Applied Biochemistry and Microbiology, vol. 47, no. 3, pp. 274278, 2011.

[10] Y. Khambhaty, K. Mody, and B. Jha, "Purification, characterization and application of a novel extracellular agarase from a marine Bacillus megaterium," Biotechnology and Bioprocess Engineering, vol. 13, no. 5, pp. 584-591, 2008.

[11] C. Zou, Z. Li, and D. Yu, "Bacillus megaterium strain XTBG34 promotes plant growth by producing 2-pentylfuran," Journal of Microbiology, vol. 48, no. 4, pp. 460-466, 2010.

[12] N. N. Prabhu, M. C. Santimano, S. Mavinkurve, S. N. Bhosle, and S. Garg, "Native granule associated short chain length polyhydroxyalkanoate synthase from a marine derived Bacillus sp. NQ-11/A2," Antonie van Leeuwenhoek, vol. 97, no. 1, pp. 4150, 2010.

[13] J. Wang, Q. Zhang, H. Huang et al., "Increasing synthetic performance of penicillin $\mathrm{G}$ acylase from Bacillus megaterium by sitedirected mutagenesis," Applied Microbiology and Biotechnology, vol. 74, no. 5, pp. 1023-1030, 2007. 
[14] J. S. He and A. J. Fulco, "A barbiturate-regulated protein binding to a common sequence in the cytochrome $\mathrm{P} 450$ genes of rodents and bacteria," Journal of Biological Chemistry, vol. 266, no. 12, pp. 7864-7869, 1991.

[15] S. Bleif, F. Hannemann, J. Zapp, D. Hartmann, J. Jauch, and R. Bernhardt, "A new Bacillus megaterium whole-cell catalyst for the hydroxylation of the pentacyclic triterpene 11-keto- $\beta$ boswellic acid (KBA) based on a recombinant cytochrome $\mathrm{P} 450$ system," Applied Microbiology and Biotechnology, vol. 93, no. 3, pp. 1135-1146, 2012.

[16] M. Eppinger, B. Bunk, M. A. Johns et al., "Genome sequences of the biotechnologically important Bacillus megaterium Strains QM B1551 and DSM319," Journal of Bacteriology, vol. 193, no. 16, pp. 4199-4213, 2011.

[17] S. V. Otari and J. S. Ghosh, "Production and characterization of the polymer polyhydroxybutyrate-copolyhydroxyvalerate by Bacillus megaterium NCIM, 2475," Current Research Journal of Biological Sciences, vol. 1, no. 2, pp. 23-26, 2009.

[18] S. V. Reddy, M. Thirumala, and S. K. Mahmood, "Production of $\mathrm{PHB}$ and $\mathrm{P}(3 \mathrm{HB}-\mathrm{co}-3 \mathrm{HV})$ biopolymers by Bacillus megaterium strain OU303A isolated from municipal sewage sludge," World Journal of Microbiology and Biotechnology, vol. 25, no. 3, pp. 391397, 2009.

[19] M. C. Santimano, N. N. Prabhu, and S. Garg, "PHA production using low-cost agro-industrial wastes by Bacillus sp. strain COL1/A6," Research Journal of Microbiology, vol. 4, no. 3, pp. 89-96, 2009.

[20] C. Ash, J. A. E. Farrow, S. Wallbanks, and M. D. Collins, "Phylogenetic heterogeneity of the genus Bacillus revealed by comparative analysis of small-subunit-ribosomal RNA sequences," Letters in Applied Microbiology, vol. 13, no. 4, pp. 202-206, 1991.

[21] K. H. Cheung and J. Gu, "Chromate reduction by Bacillus megaterium TKW3 isolated from marine sediments," World Journal of Microbiology and Biotechnology, vol. 21, no. 3, pp. 213219, 2005.

[22] R. E. Gordon, W. C. Haynes, and C. H. N. Pang, The Genus Bacillus, Agriculture handbook No. 437, Agricultural Research Service, U.S. Department of Agriculture, Washington, DC, USA, 1973.

[23] M. Kanjanamaneesathian, C. Kusonwiriyawong, A. Pengnoo, and L. Nilratana, "Screening of potential bacterial antagonists for control of sheath blight in rice and development of suitable bacterial formulations for effective application," Australasian Plant Pathology, vol. 27, no. 3, pp. 198-206, 1998.

[24] J. M. Lim, C. O. Jeon, S. M. Lee et al., "Bacillus salarius sp. nov., a halophilic, spore-forming bacterium isolated from a salt lake in China," International Journal of Systematic and Evolutionary Microbiology, vol. 56, no. 2, pp. 373-377, 2006.

[25] R. A. Slepecky and H. E. Hemphill, "The genus Bacillusnonmedical," in The Prokaryotes, A. Balows, H. G. Truper, M. Dworkin, W. Harder, and K. H. Schleifer, Eds., pp. 1663-1696, Springer, New York, NY, USA, 2nd edition, 1992.

[26] D. Claus and R. C. W. Berkeley, "Endospore-forming grampositive rods and cocci," in Genus Bacillus in Bergey's Manual of Systematic Bacteriology, P. H. A. Sneath, N. S. Mair, M. E. Sharpe, and J. G. Holt, Eds., vol. 2, pp. 1104-1207, Williams and Wilkins, Baltimore, Md, USA, 1986.

[27] K. H. Law, Y. C. Leung, H. Lawford, H. Chua, W. Lo, and P. $\mathrm{H}$. Yu, "Production of polyhydroxybutyrate by Bacillus species isolated from municipal activated sludge," Applied Biochemistry and Biotechnology A, vol. 91-93, pp. 515-524, 2001.
[28] I. Berber and C. Cokmus, "Characterization of Bacillus sphaericus strains by Native-PAGE," Bulletin of Pure and Applied Sciences, vol. 20, no. 1, pp. 17-21, 2001.

[29] D. Xu and J. Cote, "Phylogenetic relationships between Bacillus species and related genera inferred from comparison of 39 end $16 \mathrm{~S}$ rDNA and 59 end 16S-23S iTS nucleotide sequences," International Journal of Systematic and Evolutionary Microbiology, vol. 53, no. 3, pp. 695-704, 2003.

[30] Y. Qingming and X. Zongping, "Rapid classification of Bacillus isolates using RAPD technique," Wuhan University Journal of Natural Sciences, vol. 2, no. 1, pp. 105-109, 1997.

[31] A. Matarante, F. Baruzzi, P. S. Cocconcelli, and M. Morea, "Genotyping and toxigenic potential of Bacillus subtilis and Bacillus pumilus strains occurring in industrial and artisanal cured sausages," Applied and Environmental Microbiology, vol. 70, no. 9, pp. 5168-5176, 2004.

[32] I. Berber, "Characterization of Bacillus species by numerical analysis of their SDS-PAGE protein profiles," Journal of Cell and Molecular Biology, vol. 3, pp. 33-37, 2004.

[33] I. Ahmed, A. Yokota, A. Yamazoe, and T. Fujiwara, "Proposal of Lysinibacillus boronitolerans gen. nov. sp. nov., and transfer of Bacillus fusiformis to Lysinibacillus fusiformis comb. nov. and Bacillus sphaericus to Lysinibacillus sphaericus comb. nov," International Journal of Systematic and Evolutionary Microbiology, vol. 57, no. 5, pp. 1117-1125, 2007.

[34] C. Ash, F. G. Priest, and M. D. Collins, "Molecular identification of rRNA group 3 bacilli (Ash, Farrow, Wallbanks and Collins) using a PCR probe test," Antonie van Leeuwenhoek, vol. 64, no. 3-4, pp. 253-260, 1993.

[35] M. Heyndrickx, L. Lebbe, K. Kersters, P. De Vos, G. Forsyth, and N. A. Logan, "Virgibacillus: a new genus to accommodate Bacillus pantothenticus (Proom and Knight 1950). Emended description of Virgibacillus pantothenticus," International Journal of Systematic Bacteriology, vol. 48, no. 1, pp. 99-106, 1998.

[36] O. Shida, H. Takagi, K. Kadowaki, and K. Komagata, "Proposal for two new genera, Brevibacillus gen. nov. and Aneurinibacillus gen. nov.," International Journal of Systematic Bacteriology, vol. 46, no. 4, pp. 939-946, 1996.

[37] J. H. Yoon, N. Weiss, K. C. Lee, I.-S. Lee, K. H. Kang, and Y.-H. Park, "Jeotgalibacillus alimentarius gen. nov., sp. nov.,a novel bacterium isolated from jeotgal with L-lysine in the cell wall, and reclassification of Bacillus marinus Ruger 1983 as Marinibacillus marinus gen. nov., comb. nov.," International Journal of Systematic and Evolutionary Microbiology, vol. 51, no. 6, pp. 2087-2093, 2001.

[38] J. Yoon, K. H. Kang, and Y. Park, "Lentibacillus salicampi gen. nov., sp. nov., a moderately halophilic bacterium isolated from a salt field in Korea," International Journal of Systematic and Evolutionary Microbiology, vol. 52, no. 6, pp. 2043-2048, 2002.

[39] A. Steinbuchel, E. Hustede, M. Liebergesell, U. Pieper, A. Timm, and H. Valentin, "Molecular basis for biosynthesis and accumulation of polyhydroxyalkanoic acids in bacteria," FEMS Microbiology Reviews, vol. 103, no. 2-4, pp. 217-230, 1992.

[40] M. S. Divyashree, T. R. Shamala, and N. K. Rastogi, "Isolation of polyhydroxyalkanoate from hydrolyzed cells of Bacillus flexus using aqueous two-phase system containing polyethylene glycol and phosphate," Biotechnology and Bioprocess Engineering, vol. 14, no. 4, pp. 482-489, 2009.

[41] P. H. A. Sneath, N. S. Mair, M. E. Sharpe, and J. G. Holt, Bergey's Manual of Systematic Bacteriology, vol. 2, Williams \& Wilkins, Baltimore, Md, USA, 2nd edition, 1986. 
[42] P. D. Vos, G. M. Garrity, D. Jones et al., Bergey's Manual of Systematic Bacteriology. The Firmicutes, vol. 3, Springer, New York, NY, USA, 2nd edition, 2009.

[43] J. Sambrook, E. F. Fritsch, and T. Maniatis, Molecular Cloning: A Laboratory Manual, Cold Spring Harbor Laboratory, Cold Spring Harbor, NY, USA, 2nd edition, 1989.

[44] M. A. Larkin, G. Blackshields, N. P. Brown et al., "Clustal W and Clustal X version 2.0," Bioinformatics, vol. 23, no. 21, pp. 29472948, 2007.

[45] K. Tamura, J. Dudley, M. Nei, and S. Kumar, "MEGA4: molecular evolutionary genetics analysis (MEGA) software version 4.0," Molecular Biology and Evolution, vol. 24, no. 8, pp. 15961599, 2007.

[46] M. I. Queipo-Ortuño, J. D. Colmenero, J. M. Reguera et al., "Rapid diagnosis of human brucellosis by SYBR green I-based real-time PCR assay and melting curve analysis in serum samples," Clinical Microbiology and Infection, vol. 11, no. 9, pp. 713-718, 2005.

[47] G. J. McCool and M. C. Cannon, "Polyhydroxyalkanoate inclusion body-associated proteins and coding region in Bacillus megaterium," Journal of Bacteriology, vol. 181, no. 2, pp. 585-592, 1999.

[48] B. H. A. Rehm, "Polyester synthases: natural catalysts for plastics," Biochemical Journal, vol. 376, no. 1, pp. 15-33, 2003.

[49] T. R. Lee, J. S. Lin, S. S. Wang, and G. C. Shaw, "PhaQ, a new class of poly- $\beta$-hydroxybutyrate (PHB)-responsive repressor, regulates phaQ and phaP (Phasin) expression in Bacillus megaterium through interaction with PHB," Journal of Bacteriology, vol. 186, no. 10, pp. 3015-3021, 2004.

[50] T. R. Shamala, A. Chandrashekar, S. V. N. Vijayendra, and L. Kshama, "Identification of polyhydroxyalkanoate (PHA)producing Bacillus spp. using the polymerase chain reaction (PCR)," Journal of Applied Microbiology, vol. 94, no. 3, pp. 369374, 2003.

[51] G. D. Haki and S. K. Rakshit, "Developments in industrially important thermostable enzymes: a review," Bioresource Technology, vol. 89, no. 1, pp. 17-34, 2003.

[52] M. Maki, K. T. Leung, and W. Qin, “The prospects of cellulaseproducing bacteria for the bioconversion of lignocellulosic biomass," International Journal of Biological Sciences, vol. 5, no. 5, pp. 500-516, 2009.

[53] H. W. Park, D. K. Bideshi, and B. A. Federici, "Properties and applied use of the mosquitocidal bacterium, Bacillus sphaericus," Journal of Asia-Pacific Entomology, vol. 13, no. 3, pp. 159168, 2010.

[54] W. Raza, W. Yang, and Q. R. Shen, "Paenibacillus polymyxa: antibiotics, hydrolytic enzymes and hazard assessment," Journal of Plant Pathology, vol. 90, no. 3, pp. 419-430, 2008.

[55] M. Schallmey, A. Singh, and O. P. Ward, "Developments in the use of Bacillus species for industrial production," Canadian Journal of Microbiology, vol. 50, no. 1, pp. 1-17, 2004.

[56] S. H. Tsai, C. P. Liu, and S. S. Yang, "Microbial conversion of food wastes for biofertilizer production with thermophilic lipolytic microbes," Renewable Energy, vol. 32, no. 6, pp. 904-915, 2007.

[57] S. P. Valappil, A. R. Boccaccini, C. Bucke, and I. Roy, "Polyhydroxyalkanoates in Gram-positive bacteria: insights from the genera Bacillus and Streptomyces," Antonie van Leeuwenhoek, vol. 91, no. 1, pp. 1-17, 2007. 

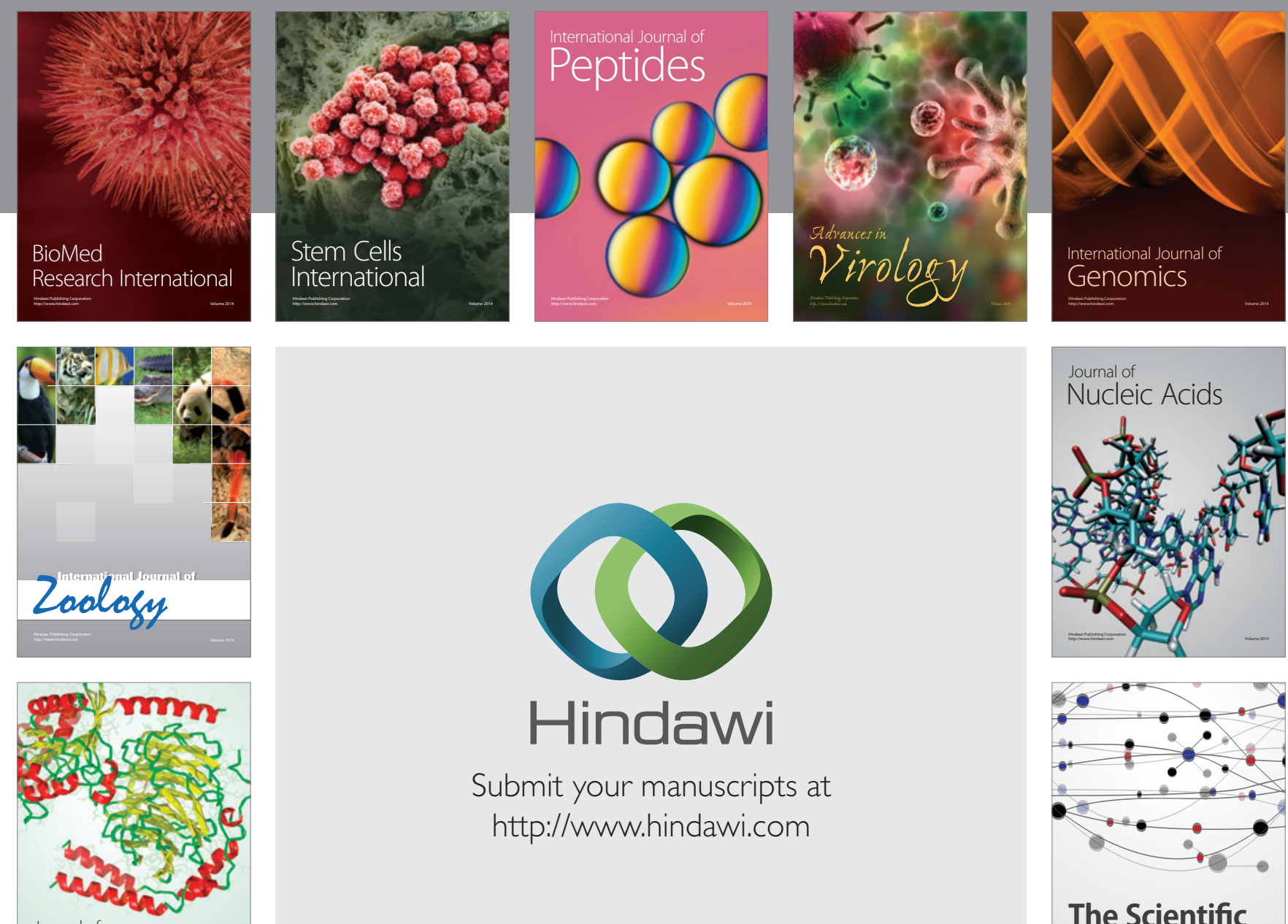

Submit your manuscripts at

http://www.hindawi.com

Journal of
Signal Transduction
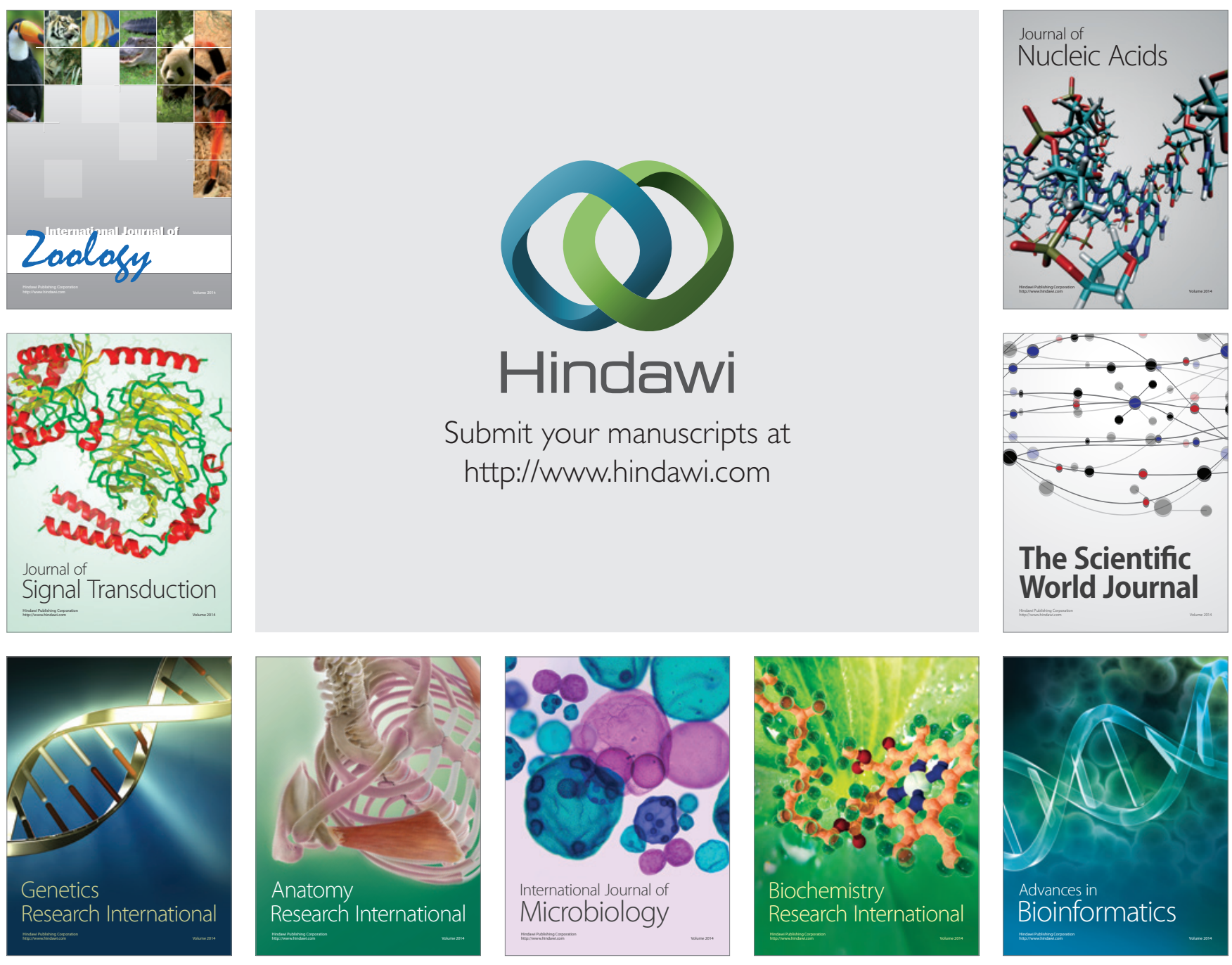

The Scientific World Journal
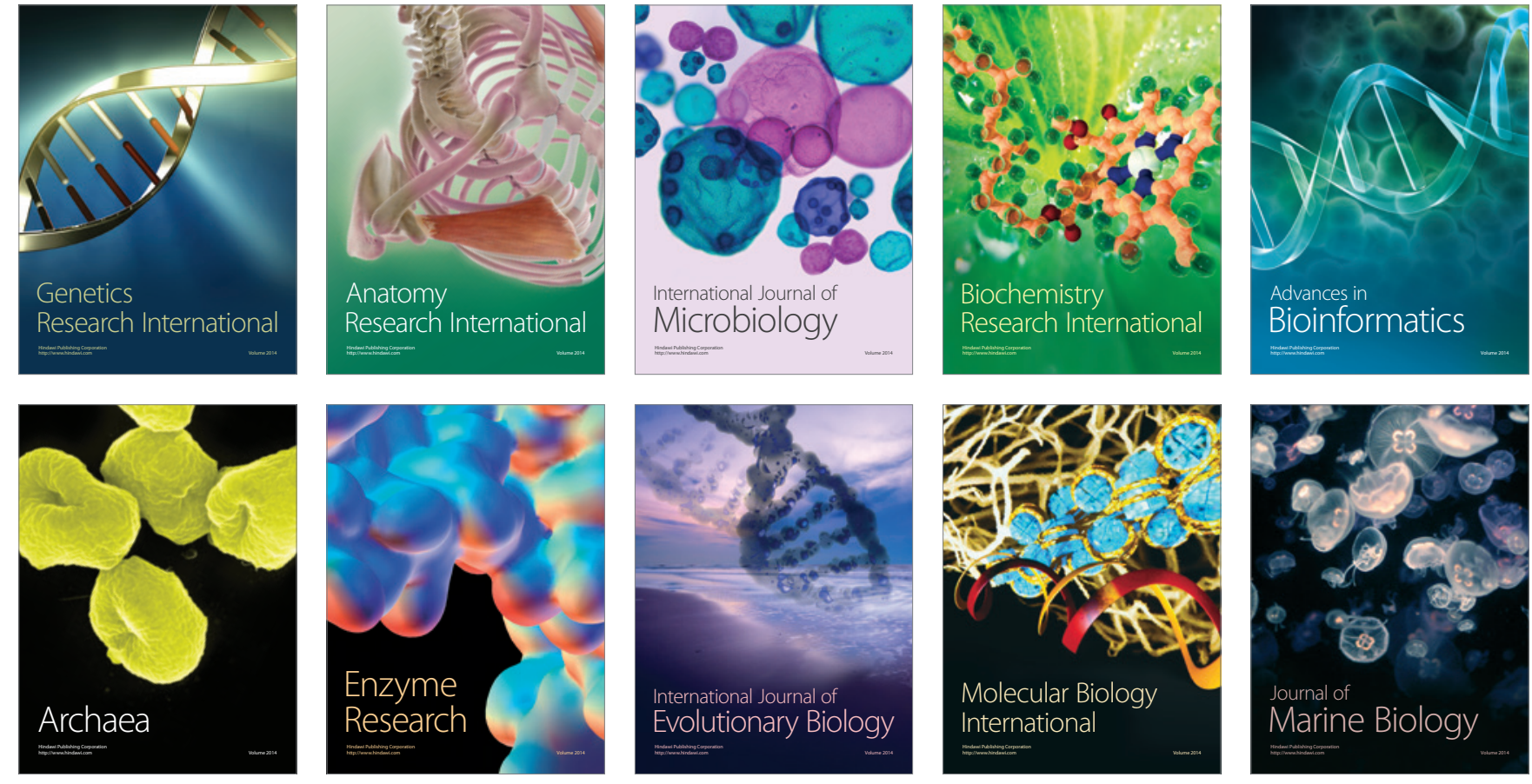